\title{
Pengaruh konsumsi nanas (Ananas comosus L. Merr) terhadap penurunan indeks plak pada anak usia 10-12 tahun di SD Inpres 4/82 Pandu
}

\author{
${ }^{1}$ Yurnila A. Embisa \\ ${ }^{2}$ Lydia Tendean \\ ${ }^{3}$ Kustina Zuliari
}

\author{
${ }^{1}$ Kandidat Skripsi Program Studi Pendidikan Dokter Gigi Fakultas Kedokteran \\ ${ }^{2}$ Bagian Biologi Fakultas Kedokteran \\ ${ }^{3}$ Program Studi Pendidikan Dokter Gigi Fakultas Kedokteran \\ Universitas Sam Ratulangi Manado \\ Email: yurnila2810@gmail.com
}

\begin{abstract}
To date, the most common oral health problem in children is dental caries. Plaque is one of the causes of caries. There are several ways to control plaque, as follows: mechanical, chemical and naturally methods. Plaque can naturally be controled by consumption of fiber-rich and watery fruits, inter alia pineapple. This study is aimed to obtain the effect of pineapple consumption on plaque index reduction in children aged 10-12 years old at SD Inpres 4/82 Pandu. This was a quasy experimental study with a pre and post-test group design. There were 48 students as samples obtained by using simple random sampling method. The result of paired t-test showed that the significance probability value was $0.000(\mathrm{p}<0.05)$, which meant that there was a significant reduction in plaque index between before and after pineapple consumption. Conclusion: Pineapple consumption could reduce plaque index in children aged 10-12 years old.
\end{abstract}

Keywords: pineapple, plaque index.

\begin{abstract}
Abstrak: Masalah kesehatan gigi dan mulut pada anak yang banyak ditemukan ialah karies gigi. Plak merupakan salah satu faktor penyebab terjadinya karies. Untuk menghilangkan plak dapat dilakukan tindakan pengontrolan plak, yaitu mekanis, kimiawi, dan alamiah. Pengontrolan plak secara alamiah dapat dilakukan dengan mengonsumsi buah yang mengandung serat dan air, antara lain buah nanas. Penelitian ini bertujuan untuk mengetahui pengaruh mengonsumsi nanas terhadap penurunan indeks plak pada anak usia 10-12 tahun. Jenis penelitian ialah eksperimental semu dengan pre and post-test group design. Sampel sebanyak 48 siswa usia 10-12 tahun yang duduk di kelas V dan VI di SD Inpres 4/82 Pandu, diperoleh dengan simple random sampling. Hasil uji paired t-test mendapatkan nilai probabilitas signifikansi $0,000(\mathrm{p}<0,05)$ yang artinya terdapat perbedaan penurunan indeks plak yang bermakna antara sebelum dan sesudah mengonsumsi nanas.

Simpulan: Konsumsi nanas dapat menurunkan indeks plak pada anak usia 10-12 tahun.

Kata kunci: nanas, indeks plak
\end{abstract}

Masalah kesehatan gigi dan mulut pada anak-anak yang banyak ditemui sampai saat ini ialah karies gigi. Karies merupakan suatu penyakit infeksi yang dihasilkan dari interaksi bakteri. Karies gigi terjadi karena proses demineralisasi dari interaksi bakteri pada permukaan gigi. Bakteri bersifat asam sehingga dalam periode waktu tertentu, asam akan merusak email gigi sehingga menyebabkan karies gigi. ${ }^{1}$ Berdasarkan Riset Kesehatan Dasar (Riskesdas) tahun 2013, masalah gigi dan mulut khususnya di Provinsi Sulawesi Utara sebesar 31,6\% dan yang mengalami karies gigi di Sulawesi Utara sebesar $5,4 \%{ }^{2}$

Plak merupakan salah satu faktor penyebab terjadinya karies. Plak yaitu deposit lunak yang membentuk biofilm 
yang melekat pada permukaan gigi, tidak berwarna, tidak terlihat kasat mata, dan mengandung bakteri. Pembersihan gigi yang kurang baik dapat menyebabkan plak semakin melekat dan tidak dapat dihilangkan hanya berkumur-kumur dengan air. Untuk menghilangkan plak perlu dilakukan tindakan pengontrolan plak. ${ }^{3-5}$

Pengontrolan plak yang digunakan terdiri dari beberapa cara yaitu: mekanis, kimiawi, dan alamiah. ${ }^{6}$ Pengontrolan plak yang dilakukan secara mekanis seperti menggosok gigi dan penggunaan benang gigi, sedangkan secara kimiawi seperti penggunaan obat kumur. Konsumsi makanan yang mengandung serat dan air bersifat tidak merangsang pembentukan plak, melainkan dapat berperan sebagai pengendali plak secara alamiah. $^{7}$

Nanas merupakan salah satu buah yang mengandung serat dan air. Dalam nanas terdapat kandungan serat sebesar 1,4 gram dan air sebesar 86,37 gram tiap 100 gram daging buah nanas. ${ }^{8}$ Nanas merupakan buah yang mempunyai kandungan sangat kompleks, dengan khasiat yang beraneka ragam. Buah nanas juga mengandung enzim bromelin yang dapat menekan pertumbuhan bakteri pembentuk plak. $^{9}$ Penelitian yang dilakukan oleh Rakhmanda bahwa nanas mempunyai efek antibakteri baik menghambat (bacteriostatik) maupun membunuh (bacterisidal) bakteri penyebab karies terutama Streptococcus mutans yang banyak terdapat pada plak. $^{10}$

Peneliti memilih buah nanas sebagai bahan penelitian karena buah ini memiliki kandungan serat dan air yang dapat berperan sebagai pengendali plak secara alamiah, harganya murah, serta banyak terdapat di Sulawesi Utara. Tanaman ini juga cukup mudah untuk dibudidayakan, karena cocok dengan iklim di Indonesia. ${ }^{11}$

Pemilihan anak usia 10-12 tahun sebagai populasi karena pada tingkat usia ini anak-anak masih kurang mengetahui dan mengerti cara memelihara kesehatan gigi dan mulut. Kelompok anak usia sekolah perlu mendapat perhatian khusus sebab pada usia ini anak sedang menjalani proses tumbuh kembang. Keadaan gigi sebelumnya akan berpengaruh terhadap perkembangan kesehatan gigi pada usia dewasa nanti, sehingga perlu pencegahan sejak usia dini. Peneliti memilih SD Inpres 4/82 Pandu sebagai populasi penelitian karena belum pernah dilakukan penelitian di sekolah ini, dan tidak adanya program Usaha Kesehatan Gigi Sekolah (UKGS), serta akses menuju ke sekolah tersebut mudah dijangkau.

Penelitian ini bertujuan untuk mendapatkan pengaruh konsumsi nanas (Ananas comosus L. Merr) terhadap penurunan indeks plak pada anak usia 1012 tahun di SD Inpres 4/82 Pandu.

\section{BAHAN DAN METODE PENELITIAN}

Jenis penelitian ini ialah eksperimental semu (quasy experimental) dengan pre and post-test group design. Populasi penelitian ialah seluruh siswa berusia 10-12 tahun yang duduk di kelas V dan VI di SD Inpres 4/82 Pandu, Jumlah sampel ditentukan dengan menggunakan rumus Slovin dan didapatkan 48 responden, diperoleh dengan simple random sampling.

Alat dan bahan yang digunakan dalam penelitian ini ialah lembar pemeriksaan, kaca mulut, sonde, pinset, nanas 100 gram/responden, disclosing solution, air dan kapas.

Pengukuran indeks plak sebelum dan sesudah mengonsumsi nanas menggunakan indeks PHP (Patient Hygiene Performance Index) menurut Podshadley dan Haley. Gigi yang diperiksa terdiri dari gigi 16, 11, 26, 36, 31, dan 46. Permukaan yang diperiksa untuk rahang atas gigi insisivus di sisi labial dan gigi molar di sisi bukal sedangkan untuk rahang bawah gigi insisivus di sisi labial dan gigi molar di sisi lingual. Pemeriksaan dilakukan pada mahkota gigi bagian fasial atau lingual dengan membagi tiap permukaan mahkota gigi menjadi lima subdivisi yaitu $M$ (mesial), D (distal), G (sepertiga tengah gingiva), $\mathrm{C}$ (sepertiga tengah), $\mathrm{I} / \mathrm{O}$ (sepertiga tengah insisal atau oklusal), Setiap area yang terdapat plak diberi 1 poin. Kategori indeks PHP yaitu: sangat 
baik (0); baik $(0,1-1,7)$; sedang $(1,8-3,4)$; dan buruk $(3,5-5) .{ }^{12}$

\section{HASIL PENELITIAN}

Penelitian ini dilaksanakan di SD Inpres 4/82 Pandu, Kelurahan Pandu Lk. IV, Kecamatan Mapanget, Kota Manado Provinsi Sulawesi Utara dengan jumlah responden sebanyak 48 siswa. Tabel 1 menunjukkan distribusi karakteristik responden berdasarkan jenis kelamin dimana perempuan berjumlah lebih banyak yaitu 32 responden $(66,67 \%)$ dibandingkan dengan laki-laki yang berjumlah 16 responden $(33,33 \%)$.

Tabel 1. Distribusi karakteristik responden berdasarkan jenis kelamin

\begin{tabular}{ccc}
\hline Jenis kelamin & n & \% \\
\hline Perempuan & 32 & 66,67 \\
Laki-laki & 16 & 33,33 \\
Total & 48 & 100 \\
\hline
\end{tabular}

Tabel 2 menunjukkan distribusi karakteristik responden berdasarkan usia. Responden terbanyak yaitu berusia 10 tahun berjumlah 21 siswa $(43,75 \%)$ dan responden yang paling sedikit yaitu berusia 12 tahun berjumlah 9 siswa $(18,75 \%)$.

Hasil pemeriksaan indeks plak pada penelitian ini menggunakan cara perhitungan Patient Hygiene Performance Index (Indeks PHP). Pemeriksaan indeks plak dibagi atas dua yaitu pemeriksaan indeks plak sebelum mengonsumsi nanas dan pemeriksaan indeks plak sesudah mengonsumsi nanas.

Tabel 2. Distribusi karakteristik responden berdasarkan usia

\begin{tabular}{ccc}
\hline Usia (tahun) & n & \% \\
\hline 10 tahun & 21 & 43,75 \\
11 tahun & 18 & 37,50 \\
12 tahun & 9 & 18,75 \\
Total & 48 & 100 \\
\hline
\end{tabular}

Tabel 3 menunjukkan indeks plak sebelum mengonsumsi nanas. Responden yang berada dalam kategori sangat baik dan baik tidak ada (0\%); responden yang berada pada kategori sedang yaitu 16 siswa $(33,33 \%)$; dan responden yang berada pada kategori buruk yaitu 32 siswa $(66,67 \%)$.

Tabel 3. Hasil pemeriksaan indeks plak sebelum mengonsumsi nanas

\begin{tabular}{cccc}
\hline Indeks plak & Kategori & $\mathbf{n}$ & $\mathbf{\%}$ \\
\hline 0 & Sangat baik & 0 & 0 \\
$0,1-1,7$ & Baik & 0 & 0 \\
$1,8-3,4$ & Sedang & 16 & 33,33 \\
$3,5-5$ & Buruk & 32 & 66,67 \\
Total & & 48 & 100 \\
\hline
\end{tabular}

Tabel 4 menunjukkan indeks plak sesudah mengonsumsi nanas. Responden yang berada dalam kategori sangat baik tidak ada $(0 \%)$; responden yang berada pada kategori baik 7 siswa $(14,59 \%)$; responden yang berada pada kategori sedang yaitu 39 siswa $(81,25 \%)$; dan responden yang berada pada kategori buruk yaitu 2 siswa $(4,16 \%)$.

Tabel 4. Hasil pemeriksaan indeks plak sesudah mengonsumsi nanas

\begin{tabular}{cccc}
\hline Indeks plak & Kategori & $\mathbf{n}$ & $\mathbf{\%}$ \\
\hline 0 & Sangat baik & 0 & 0 \\
$0,1-1,7$ & Baik & 7 & 14,59 \\
$1,8-3,4$ & Sedang & 39 & 81,25 \\
$3,5-5$ & Buruk & 2 & 4,16 \\
Total & & 48 & 100 \\
\hline
\end{tabular}

Pada uji normalitas data menggunakan uji Shapiro-Wilk didapatkan data terdistribusi normal sehingga digunakan uji paired t-test untuk melihat pengaruh konsumsi nanas terhadap penurunan indeks plak (Tabel 5). Hasil analisis menggunakan uji paired t-test menunjukkan bahwa nilai signifikansi $0,000 \quad(\mathrm{p}<0,05) . \quad$ Dengan demikian dapat dinyatakan bahwa terdapat perbedaan penurunan indeks plak yang bermakna antara sebelum dan sesudah mengonsumsi nanas. 
Tabel 5. Hasil analisis uji paired t-test

\begin{tabular}{cccccl}
\hline Indeks plak & $\mathrm{n}$ & Mean & Std deviasi & Std error & Sig \\
\hline Pre-test & 48 & 3,548 & 0,6230 & 0,0899 & 0,000 \\
Post-test & 48 & 2,494 & 0,5385 & 0,0777 & \\
\hline
\end{tabular}

\section{BAHASAN}

Berdasarkan hasil penelitian ini, pada pemeriksaan indeks plak awal sebelum mengonsumsi buah nanas menunjukkan 32 responden memiliki indeks plak dengan kategori buruk dan 16 responden dengan kategori sedang. Setelah mengonsumsi buah nanas terjadi penurunan indeks plak yaitu terdapat 7 responden dengan kategori baik, 39 responden dengan kategori sedang, dan 2 responden dengan kategori buruk. Pemeriksaan indeks plak awal menunjukkan responden dengan kategori sedang dan buruk dikarenakan pemeriksaan dilakukan sesudah jam istirahat. Pada penelitian ini, penurunan indeks plak terlihat masih terdapat 2 responden dengan kategori buruk, hal ini dikarenakan kedua respoden tersebut memiliki tingkat kebersihan gigi dan mulut yang sangat buruk, sehingga meskipun responden telah mengonsumsi buah nanas namun penurunan indeks plak tetap pada kategori buruk.

Hasil analisis data diperoleh skor ratarata indeks plak sebelum mengonsumsi nanas sebesar 3,548 dan skor rata-rata indeks plak sesudah mengonsumsi nanas sebesar 2,494. Rata-rata selisih penurunan indeks plak sebesar 1,054. Berdasarkan uji paired t-test nilai probabilitas signifikansi $0,000(\mathrm{p}<0,05)$ sehingga dapat dinyatakan bahwa terdapat perbedaan penurunan indeks plak yang bermakna antara sebelum dan sesudah mengonsumsi buah nanas. Hasil penelitian ini serupa dengan hasil penelitian yang dilakukan oleh Mukti ${ }^{13} \mathrm{di}$ Panti Asuhan Yayasan Nur Hidayah Surakarta yang menunjukkan adanya selisih penurunan indeks plak sebelum dan sesudah mengonsumsi buah berserat. Konsumsi buah-buahan segar yang kaya akan serat dan air dapat melancarkan pembersihan sendiri pada gigi (self cleansing), sehingga luas permukaan plak dapat dikurangi dan karies gigi dapat dicegah. ${ }^{14}$ Penelitian lain juga menyebutkan bahwa penurunan indeks plak dapat terjadi karena mengonsumsi makanan berserat dan padat yang mengakibatkan meningkatnya intensitas dan lama pengunyahan. Gerakan mengunyah akan merangsang sekresi saliva yang mengandung agen antibakteri. Saliva juga dapat menghilangkan atau membilas sisasisa makanan pada gigi, menetralisasi zatzat asam yang ada, dan melarutkan komponen gula dari sisa makanan yang terperangkap dalam sela-sela pit dan fisur permukaan gigi. ${ }^{15}$ Kebiasaan mengonsumsi makanan berserat juga bersifat tidak merangsang pembentukan plak, melainkan dapat berperan sebagai pengendali plak secara alamiah. ${ }^{16}$

Pengontrolan plak sampai saat ini masih mengandalkan kontrol plak secara mekanis yaitu seperti menggosok gigi dan penggunaan benang gigi, dan secara kimiawi yaitu berkumur dengan menggunakan obat kumur yang mengandung antibakteri. $^{17}$ Dalam penelitian ini digunakan kontrol plak secara alamiah yaitu dengan cara mengonsumsi buah yang mengandung serat dan air yaitu 100 gram buah nanas diberikan kepada responden. Pemilihan buah nanas sebagai bahan penelitian karena buah nanas merupakan salah satu buah yang mengandung serat dan air yang cukup tinggi. Penelitian yang dilakukan oleh Rakhmanda pada tahun 2008 mengatakan bahwa buah nanas mengandung enzim bromelin yang berefek antibakteri baik menghambat maupun membunuh bakteri penyebab karies terutama Streptococcus mutans yang banyak terdapat pada plak. ${ }^{10}$

Penurunan indeks plak pada penelitian ini juga selain karena mengonsumsi buah nanas juga karena siswa-siswi SD Inpres 
4/82 Pandu memiliki sikap yang kooperatif saat menjadi responden serta berkemampuan dalam menangkap dan memahami instruksi yang diberikan oleh peneliti dengan sangat baik, sehingga apa yang diharapkan peneliti dapat terlaksanakan. Hal ini juga sejalan dengan penelitian yang dilakukan oleh Purba $^{18}$ yang menyatakan bahwa sikap dan perilaku anak mempunyai peran yang sangat besar terhadap status kesehatan anak tersebut.

\section{SIMPULAN}

Berdasarkan hasil penelitian ini dapat disimpulkan bahwa terdapat pengaruh konsumsi nanas terhadap penurunan indeks plak pada anak usia 10-12 tahun di SD Inpres 4/82 Pandu.

\section{SARAN}

Bagi institusi kesehatan, perlu adanya upaya berkelanjutan dari tenaga kesehatan di puskesmas untuk memberikan pengetahuan kepada masyarakat tentang pengontrolan plak dengan cara mengonsumsi buah yang mengandung serat dan air untuk pencegahan karies gigi.

Bagi masyarakat, dianjurkan untuk mengonsumsi buah yang mengandung serat dan air seperti nanas untuk mengurangi plak sehingga membantu mencegah terjadinya karies gigi.

\section{DAFTAR PUSTAKA}

1. Mustika MD. Insidensi karies gigi pada anak usia prasekolah di TK Merah Mandiangin Martapura periode 20122013. Dentino J. 2014;2:200-1.

2. Riset Kesehatan Dasar. Badan Penelitian dan Pengembangan Kesehatan. Jakarta: Departemen Kesehatan Republik Indonesia, 2013; p. 111-2.

3. Bakar A. Kedokteran Gigi Klinis (2nd ed). Yogyakarta: Quantum, 2012; p. 109.

4. Haida KE. Perbandingan efektivitas mengunyah buah pir dan bengkuang terhadap penurunan indeks plak. Dentino J. 2014;2:25.

5. Hamsar A. Perbandingan sikat gigi yang berbulu halus (soft) dengan sikat gigi yang berbulu sedang (medium) terhadap manfaatnya menghilangkan plak pada anak usia 9-12 tahun di SD Negeri 060830 Kecamatan Medan Petisah tahun 2005. PANNMED J. 2006;1:20.

6. Penda PAC, Kaligis SHM, Juliatri. Perbedaan indeks plak sebelum dan sesudah pengunyahan buah apel. eG. 2015;3: 381.

7. Huda HH, Aditya G, Praptiningsih RS. Efektivitas konsumsi buah apel (Pyrus malus) jenis Fuji terhadap skor plak gigi dan $\mathrm{pH}$ saliva. Medali J. 2015;2(1):10.

8. Sidi NC, Widowati E, Nursiwi A. Jurnal Aplikasi Teknologi Pangan. Surakarta: Indonesian Food Technologists. 2014;3:122.

9. Angraeni DP, Rahmawati AD. Efektivitas daya antibakteri ekstrak kulit nanas (Ananas comosus) terhadap pertumbuhan Streptococcus mutans [Skripsi]. Yogyakarta: Universitas Muhammadiyah. Available from: thesis.umy.ac.id.datapublik.

10. Rakhmanda AP. Perbandingan efek antibakteri jus nanas (Ananas comosus L. Merr) pada berbagai konsentrasi terhadap Streptococcus mutans [Karya tulis ilmiah]. Semarang: Universitas Diponegoro; 2008.

11. Astoko EP. Strategi pengembangan agribisnis nanas (Ananas comosus L. Merr) di Kabupaten Kediri Provinsi Jawa Timur. Jurnal Manajemen Agribisnis. 2014;14:90.

12. Marya CM. Dental indices. In: Marya CM, editor. A Textbook of Public Health Dentistry (1st ed). New Delhi: Jaypee Publisher, 2011; p. 192-3.

13. Mukti NAK. Pengaruh mengunyah buah stroberi (Fragaria chiloensis L.) terhadap hambatan pembentukan plak gigi pada remaja usia 12-18 tahun di Panti Asuhan Nur Hidayah Kota Surakarta [Skripsi]. Surakarta: Universitas Muhammadiyah; 2014.

\section{Hidayanti L, Lina N, Bachtiar KR. Peran} buah dan sayur dalam menurunkan keparahan karies gigi pada anak. [online] [cited 2016 Aug 18]. 2012. Available from: http://kesmas.unsoed.ac.id/sites/ default/files/file-unggah/Lilik\%20 Hidayanti-17.pdf. 
15. Chemiawan E, Riyanti E, Fransisca F. Perbedaan tingkat kebersihan gigi dan mulut antara anak vegetarian dan non vegetarian di Vihara Maitreya Pusat Jakarta [Tesis]. Bandung: Pediatric Dentistry Faculty of Dentistry Padjadjaran University; 2015.

16. Stegeman CA, Davis JR. The dental hygienist's guide to nutritional care (3rd ed). St. Louis: Saunders Elsevier, 2010; p. 352-362.
17. Ramayanti S. Peran makanan terhadap kejadian karies gigi. Jurnal Kesehatan Masyarakat. 2013;7(2):93.

18. Purba TR. Perilaku kebersihan gigi dan perbedaan status oral higiene murid kelas V SD di daerah rural Kecamatan Pantai Cermin dan daerah urban Kecamatan Medan Barat [Skripsi]. Medan: FKG Universitas Sumatera Utara; 2009. 